\title{
Основні показники оцінювання придатності санаторно-курортного закладу для здійснення лікувально-оздоровчого туризму
}

\author{
Бабов К. Д., Дмитрієва Г. О., Тихохід Л. В., Кубиніна Л. В., Рожков В. С. \\ дУ "Український науково-дослідний інститут медичної реабілітації та курортології МОЗ України", \\ м. Одеса, Україна
}

Актуальність. Багатий та різноманітний ресурсно-ландшафтний потенціал країни, наявність широкого арсеналу функціонуючих санаторно-курортних закладів, кожний 3 яких має свої неповторні особливості, потребують постійного удосконалення їньої діяльності, особливо в сучасних економічних умовах, а саме - спрямування їх на здійснення лікувально-оздоровчого туризму.

Мета дослідження: розробити анкету обстеження санаторно-курортного закладу щодо його придатності до здійснення лікувально-оздоровчого туризму.

Матеріали та методи дослідження. Соціологічні, методи системного аналізу, емпіричні.

Результати дослідження та їх обговорення. Розроблено анкету обстеження санаторно-курортного закладу щодо його можливостей до здійснення лікувальнооздоровчого туризму, яку опрацьовано на 30 оздоровчих закладах різних форм власності та відомчого підпорядкування. Чинниками перспективності закладу для медичного туризму є:

- загальна характеристика санаторнокурортного закладу (назва, адреса, контакти, форма власності, підпорядкованість, кількість ліжок, сезонність, акредитація, географічна, природна, кліматична характеристики й ін.);
- інфраструктурна характеристика (територія, сервіс проживання, харчування, відпочинку);

- медична характеристика (діагностично-інструментальне та лабораторне оснащення);

- лікувальна база (методи лікування, лікувальні кабінети, використання природних лікувальних ресурсів, апаратна фізіотерапія, ЛФК тощо);

- штати (категорія, науковий ступінь, знання іноземної мови);

- наявність умов для оздоровлення та відпочинку (басейн, косметологічний кабінет, СПА-терапія, сауна, концертний зал, екскурсії тощо).

Висновки. Аналіз анкети дозволяє оцінити придатність закладу для здійснення лікувально-оздоровчого туризму.

Перспективи подальших досліджень. Буде визначено напрями медичного туризму, обгрунтовано комплексні програми з різними термінами перебування та створено мапу лікувально-оздоровчого туризму на курортах України.

Ключові слова: санаторно-курортний заклад, медичний туризм.

Конфлікт інтересів. Немає. 